\title{
QUALITY DIFFERENCES OF BOER LIQUID SEMEN DURING STORAGE WITH ADDITION SWEETORANGEESSENTIAL OIL IN TRIS YOLK AND GENTAMICIN EXTENDER
}

\author{
Sukma Aditya Sitepu ${ }^{*}$, Zaituni Udin ${ }^{2}$, Jaswandi $^{2}$, Hendri $^{2}$ \\ ${ }^{1}$ Department of Animal Husbandry, Faculty of Agriculture, Pembangunan Panca Budi University, Medan, Indonesia \\ ${ }^{2}$ Faculty of Animal Husbandry, Andalas University, Padang, Indonesia \\ *Correspondence Author: sukmaaditya@ dosen.pancabudi.ac.id
}

\begin{abstract}
The purpose of this study was to know the quality of Boer liquid semen during storage by adding sweet orange essential oil and gentamicin into the tris yolkextender.The semenlongevity test was carried out by storing semen in a closed tube at room temperature and refrigerator, and evaluated motility and Viability every 3 hours at room temperature and 12 hours in refrigerator. The results showed that the characteristics of the liquid semen, with the addition of $1 \%$ of essential oils showed percentage of motility and Viability significantly higher than $0.5 \%$ and without the addition of essential oil, either stored at room temperature or in the refrigerator. This may be related to the content of essential oils of sweet orange peel containing flavonoids and antibacterials that are capable of maintaining liquid semen quality of Boer Goat.In addition, gentamicin contains antibacterials capable of suppressing the growth of bacteria which can damage and durabilitythe spermatozoa.
\end{abstract}

Keywords: Boer Goat,Gentamicin, Liquid semen, Sweet orange

\section{INTRODUCTION}

Increased purchasing power and public awareness about the importance of protein needs for the body make the demand for meat in Indonesia is increasing. It is necessary to think about how to meet those needs. One way that can be done is to do meat-producing livestock business, such as cattle breeding goats.

One of the causes of underdevelopment of goat farms in Indonesia is the poor quality of local goats. Local goats have low body weight and growth so it is less profitable if used for goat farming business. But the local goat also has the advantage that is resistant and easy to adapt to the environment in Indonesia.

To improve the quality of genetic quality of local goats in Indonesia can be done with cross breeding with superior goats. By doing cross breeding we can get better quality goats. One of the goats that can be used is the Boer Goat.

Boer Goats have several advantages such as high body weight, high carcass, fast growth and high litter size (Memon et al, 2011).It is expected to conduct cross breading with local goat Boer goat will be obtained which has a weight and high growth derived from Boer goats and a good adaptability of local goats.

Artificial Insemination can be a solution to cultivate the livestock business (Toelihere, 1993). By doing Artificial Insemination, breeders do not need to pay the cost of maintenance and purchase of superior male goats are very expensive. However, Artificial Insemination has several disadvantages, including the growth of bacteria in the semen and the occurrence of cold shock at the time of dilution of liquid semen.

Some studies use gentamicin as an antibacterial in liquid cement. Gentamicin can also be combined with other antibiotics such as penicillin to improve the quality of liquid cement (Zaituni, 2012). In addition to antibiotics, this time began to develop other alternatives as antibacterials such as sweet orange essential oil. The combination of Essential oil sweet orange is expected to be used as antibacterial on Boer goat's frozen cement and the antioxidant contained therein can be used to minimize the damage caused by cold shock.

\section{MATERIALS AND METHODS}

Experimental site, animals and management the experiment was carried out at theLaboratory Research Station Goat Sei Putih, Deli Serdang, North Sumatra in April 2017.Research using fresh semen quality boer goat well accommodated by using an artificial vagina goat. Diluent used is tris egg yolks with the compositions include tris 
diluent, citric acid, fructose, glycerol, egg yolk, aquabidest and gentamicin. The $2 \%$ of eosin is used as a medium observation viability.

\subsection{Research Procedure}

This research uses Boer Goat semen. The cement shelter uses an artificial vaginal method, the Boer stud collected by semen using a method such as the activity of natural mating. The shelter was carried out in the morning from using an artificial vagina $\left(40^{\circ} \mathrm{C}-42^{\circ} \mathrm{C}\right)$ which was previously given Vaseline. Subsequently, we performed the manufacture of tris yolkextender with the addition of gentamicin and sweet orange essential oil, then mixed fresh cement boer goats. After dilution is done observation of liquid cement at room temperature and at refrigerator

\subsection{Statistical Analysis}

The mean Liquid semen parameters of motility and viabilityfor the10 trial carried out during this study were subjected to analysis of variance (ANOVA) using SAS and Duncan Multiple Range Test. The treatment provided is: $\mathrm{T}_{1}=$ Gentamicin

$\mathrm{T}_{2}=$ Gentamicin + Essential oil $0,5 \%$

$\mathrm{T}_{3}=$ Gentamicin + Essential oil $1 \%$

\subsection{Evaluation of Microscopic Sperm Parameters}

Observations were made every 3 hours at room temperature and 12 hours at refrigerator temperature. The observations made on liquid cement of Boer goats are:

Motility: The percentage of spermatozoa moving progressively forward. The evaluation was done by observing spermatozoa in eight different visual field with a light microscope magnification 400 times.

Viability : Percentage of dead spermatozoa after thawing was evaluated with eosin staining (eosin-Y 1.67g and sodium citrate $2.9 \mathrm{~g}$ dissolved in $100 \mathrm{ml}$ distilled water) as described by (Ogbuewu et al, 2010). The evaluation was done at a minimum of 200 spermatozoa was observed using a light microscope magnification of 400 times. Live spermatozoa characterized by a head that do not absorb the dye, while the die is characterized by a red head

\section{RESULTS AND DISCUSSION}

Interest on the diluent supplied fresh semen is as a medium where spermatozoa are alive and should be able to meet the nutritional requirements and do not reduce the power of the sperm fertility(Purdy, 2010). Spermatozoa can not survive for long periods of time unless they add various elements into semen (Toelihere, 1993). To determine the quality of liquid cement one of them is from the value motility and viability of spermatozoa (Rizal and Herdis, 2008).

Recapitulation of the research results can be seen in Table 1 and Table 2 . Table 1 shows the difference in quality of Boer goat liquid semen from 0 hours to 24 hours at room temperature, whereas the observations at refrigerator temperatures shown in Table 2. The value of motility of spermatozoa is one of the most important factors in artificial insemination programs. In the opinion of Hafez and Hafez(2000) that the motility of spermatozoa or spermatozoa motility is one of the determinants of success of spermatozoa to reach the ovum in fallopian tube and the simplest way in the assessment of sperm for artificial insemination program.

At room temperature storage, treatment $3(\mathrm{~T} 3$ = gentamicin + Essential oil 1\%) showed a significantly higher percentage of motility ( $\mathrm{P}<0.05)$ compared to treatment $1(\mathrm{~T} 1=$ gentamicin) after 18 hours of storage at $22.49 \pm$ $6.39 \%$ and $12.45 \pm 5.39 \%$. Observation viability conveniently indicates the highest percentage of the value contained in the T3 and the lowest value at T1. T3 showed significantly higher values $(\mathrm{P}<0.05)$ than T1 after 9 hours of storage, respectively of $64.25 \pm 2.54 \%$ and $60.37 \pm 3.74 \%$.

On storage in refrigerator, T3 showed a significantly higher percentage of motility $(\mathrm{P}<0.05)$ than with $\mathrm{T} 1$ after 60 hours of storage, respectively $40.34 \pm 4.35 \%$ and $33.36 \pm 5.21 \%$. Meanwhile, based on the percentage value of viability, T3 showed a higher real value $(\mathrm{P}<0.05)$ than the $\mathrm{T} 1$ treatment viability percentage after 48 hours of storage, $(62.45 \pm 3.85 \%$ and $58.39 \pm 2.63 \%)$. However, based on the percentage value of motility, T2 showed no significant difference with other treatments, both in storage of room temperature and refrigerator. Meanwhile, based on the percentage value of viability, T2 showed significant differences with other treatments after 18 hours onroom temperature and 72 hours onthe refrigerator.

The results showed that all treatments with the addition of sweet orange essential oil and gentamicin in tris yolk extender meet the standard if it will be frozen semen because it has a motility percentage value 70 to 75 . The condition of the cement manufacturing liquid will freeze one of them is having a percentage motility values above $70 \%$ (Toelihere, 1993). In the storage of liquid cement at room temperature only able to survive for 9 hours with the highest motility on T3 (45.74\%) and lowest on T1 (40.73\%). At storage 12 hours to 24 hours cement can not be used 
because it has motility less than $40 \%$. The motility requirement for the Artifical Insemination program is to have a motility percentage of at least $40 \%$ (Evans and Maxwell, 1987).

Table 1. Percentage of progressive motility (M\%) and Viability (V\%) semen at room temperature

\begin{tabular}{cccc}
\hline \hline & & & Treatment \\
\cline { 2 - 4 } Hours & T1 & T2 & T3 \\
\hline & & Motility $(\%)$ & $75,83 \pm 5,38$ \\
0 & $70,36 \pm 4,58$ & $72,36 \pm 7,48$ & $58,54 \pm 3,58$ \\
6 & $59,27 \pm 3,84$ & $57,48 \pm 6,84$ & $54,48 \pm 3,39$ \\
9 & $55,37 \pm 6,46$ & $51,47 \pm 4,57$ & $45,74 \pm 7,39$ \\
12 & $40,73 \pm 5,20$ & $44,75 \pm 5,64$ & $36,57 \pm 7,29$ \\
15 & $29,45 \pm 4,47$ & $35,46 \pm 5,68$ & $30,59 \pm 7,37$ \\
18 & $22,78 \pm 5,48$ & $27,34 \pm 8,56$ & $22,49 \pm 6,39^{\mathrm{a}}$ \\
21 & $12,45 \pm 5,39^{\mathrm{b}}$ & $19,75 \pm 6,46^{\mathrm{ab}}$ & $10,48 \pm 5,31^{\mathrm{a}}$ \\
24 & $7,29 \pm 3,38^{\mathrm{b}}$ & $8,75 \pm 6,97^{\mathrm{ab}}$ & $6,49 \pm 3,73^{\mathrm{a}}$ \\
& $3,49 \pm 4,21^{\mathrm{b}}$ & $4,65 \pm 3,56^{\mathrm{ab}}$ & \\
0 & & & $84,34 \pm 4,23$ \\
3 & & Viability $(\%)$ & $74,36 \pm 5,56$ \\
6 & $80,65 \pm 4,46$ & $82,35 \pm 3,95$ & $70,57 \pm 3,78$ \\
9 & $75,93 \pm 4,70$ & $73,55 \pm 3,57$ & $64,25 \pm 2,54^{\mathrm{a}}$ \\
12 & $68,62 \pm 2,13$ & $68,96 \pm 2,63$ & $60,85 \pm 2,85^{\mathrm{a}}$ \\
15 & $60,37 \pm 3,74^{\mathrm{b}}$ & $63,46 \pm 3,62^{\mathrm{ab}}$ & $54,63 \pm 3,35^{\mathrm{a}}$ \\
18 & $55,54 \pm 2,68^{\mathrm{b}}$ & $57,26 \pm 3,29^{\mathrm{ab}}$ & $47,37 \pm 3,75^{\mathrm{a}}$ \\
21 & $48,53 \pm 4,72^{\mathrm{b}}$ & $52,98 \pm 3,64^{\mathrm{ab}}$ & $42,25 \pm 3,45^{\mathrm{a}}$ \\
\hline & $42,76 \pm 2,54^{\mathrm{c}}$ & $45,38 \pm 2,22^{\mathrm{b}}$ & $35,34 \pm 2,73^{\mathrm{a}}$ \\
\hline
\end{tabular}

Values with different superscripts within column differ significantly at $P<0.05$

Table 2. Percentage of progressive motility (M \%) and Viability (V \%) semen at refrigerator

\begin{tabular}{|c|c|c|c|}
\hline \multirow{2}{*}{ Hours } & \multicolumn{3}{|c|}{ Treatment (million cells/mL) } \\
\hline & $\mathrm{T} 1$ & $\mathrm{~T} 2$ & $\mathrm{~T} 3$ \\
\hline & \multicolumn{3}{|c|}{ Motility (\%) } \\
\hline 0 & $70,73 \pm 4,25$ & $72,35 \pm 4,48$ & $75,74 \pm 5,23$ \\
\hline 12 & $58,35 \pm 3,84$ & $60,29 \pm 5,56$ & $60,32 \pm 5,53$ \\
\hline 24 & $51,56 \pm 5,56$ & $52,56 \pm 4,85$ & $54,64 \pm 4,85$ \\
\hline 36 & $45,21 \pm 4,36$ & $45,43 \pm 4,30$ & $48,25 \pm 3,38$ \\
\hline 48 & $38,67 \pm 3,84$ & $41,83 \pm 3,14$ & $44,75 \pm 5,85$ \\
\hline 60 & $33,36 \pm 5,21^{\mathrm{b}}$ & $35,12 \pm 5,58^{\mathrm{ab}}$ & $40,34 \pm 4,35^{\mathrm{a}}$ \\
\hline 72 & $25,63 \pm 5,33^{b}$ & $29,54 \pm 4,23^{\mathrm{ab}}$ & $33,05 \pm 5,65^{\mathrm{a}}$ \\
\hline 84 & $17,36 \pm 2,54^{b}$ & $20,95 \pm 5,63^{\mathrm{ab}}$ & $28,64 \pm 5,21^{\mathrm{a}}$ \\
\hline \multirow[t]{2}{*}{96} & $10,35 \pm 3,56^{\mathrm{b}}$ & $17,48 \pm 3,24^{\mathrm{ab}}$ & $19,21 \pm 3,75^{a}$ \\
\hline & \multicolumn{3}{|c|}{ Viability (\%) } \\
\hline 0 & $79,28 \pm 4,47$ & $81,65 \pm 5,58$ & $83,58 \pm 3,57$ \\
\hline 12 & $74,63 \pm 2,59$ & $73,73 \pm 3,74$ & $75,43 \pm 4,62$ \\
\hline 24 & $68,30 \pm 3,39$ & $70,31 \pm 4,21$ & $71,57 \pm 4,47$ \\
\hline 36 & $62,54 \pm 3,67$ & $63,58 \pm 3,04$ & $65,74 \pm 3,37$ \\
\hline 48 & $58,39 \pm 2,63^{\mathrm{b}}$ & $60,42 \pm 4,57^{\mathrm{ab}}$ & $62,45 \pm 3,85^{\mathrm{a}}$ \\
\hline 60 & $53,75 \pm 2,54^{\mathrm{b}}$ & $57,51 \pm 4,23^{\mathrm{b}}$ & $58,61 \pm 4,63^{a}$ \\
\hline 72 & $47,34 \pm 1,38^{c}$ & $52,69 \pm 5,95^{\mathrm{b}}$ & $50,35 \pm 2,82^{a}$ \\
\hline 84 & $43,73 \pm 4,44^{c}$ & $45,35 \pm 3,53^{\mathrm{b}}$ & $47,61 \pm 4,35^{\mathrm{a}}$ \\
\hline 96 & $37,35 \pm 2,34^{c}$ & $41,56 \pm 2,58^{b}$ & $44,56 \pm 2,61^{a}$ \\
\hline
\end{tabular}

Values with different superscripts within column differ significantly at $P<0.05$ 
Storage of liquid cement at room temperature is shorter compared to refrigenator temperature. Liquid semen storage at refrigerator temperatures is beneficial when Artificial Insemination requires transportation and to avoid spermatozoa damage by changes in temperature and sunlight effects. The optimum temperature for aqueous cement storage is $5^{0} \mathrm{C}$ or lower depending on the increase in cooling, whereas temperatures above $5^{0} \mathrm{C}$ can inhibit metabolic activity and motility (Ogbuewu et al, 2010).

Viability determines the quality of Boer goat's liquid cement. The purpose of the observation of viability is to see the percentage or how much spermatotoa live by the eosin staining method. Spermatozoa that do not move are not necessarily dead. Live spermatozoa are colorless head for no or very little suck dye whereas dead spermatozoa is the head of the red because of high cell wall permeability. The immobile spermatozoa may not necessarily die so as not to absorb the color, whereas the interpretation of a moving and immobile base is considered immotile (Aboagla andTerada, 2004).

The presence of dead spermatozoa may decrease the quality of Boer goat's liquid semen. Spermatozoa die during storage will also be a negative effect on the spermatozoa are alive, because dead cells will release Oxydase Aromatic Amino Acids which can trigger the formation of hydrogen peroxide and toxic (Viswanath and Shannan, 2000). Brinsko et al. (2003) stated that the addition of dead spermatozoa to liquid cement by $50 \%$ at the final concentration of $100 \times 106$ cells / mL significantly decreased motility and the membrane integrity percentage (Hafez and Hafez, 2000).

In this research,all treatments contain the same energy source. The liquid cement with higher spermatozoa concentration (meaning thinner and less energy source) will more rapidly metabolize fructose and decrease the $\mathrm{pH}$ of the media, so many spermatozoa are dead. Liquid cement storage at a lower sperm concentration has a relatively better quality with a longer shelf life as compared to the higher concentrations. This may be related to the limitations of the energy source, $\mathrm{pH}$ and osmolarity media (Wendt et al., 2002), the amount of entrained plasma, as well as the number of dead spermatozoa (Brinsko et al., 2003).

Sweet orange essential oil has limonen and linalol which can act as antibacterial (Fisher and Phillips, 2006). Adding the essential oil of the sweet orange to the diluent can increase the motility and viability of Boer goat's liquid cement as it minimizes the bacteria contained in the liquid cement. In addition, sweet orange essential oils also contain flavonoids that contain antioxidants. Antioxidants that contain free radicals that can prevent a decrease in the percentage of motility and viability of spermatozoa during the storage of Boer goat's liquid cement (Feradis, 1999).

The use of antibiotics such as gentamicin in a diluent of cement has been done, even more than one antibacterial (Hasan et al, 2000). An antibacterial combination was performed to obtain the best antibacterial composition that could inhibit bacterial growth but did not decrease the quality of the liquid cement. The use of antibacterial combinations widely used in cement diluents according to Rizal and Herdis (2008) are SP (Streptomycin and Penicillin) and Hasan et al. (2000) in buffaloes namely GTLS (Gentamicin, Tylosin and Linco-Spectin). The results of studies showing positive results due to the combination of sweet orange Essential oil and gentamicin containing antibacterial and antioxidant that improves the quality of liquid cement Boer goats.

\section{CONCLUSION}

All treatments in this study are of good quality and can be stored up to 9 hours at room temperature and 48 hours at refrigerator temperature. The best treatment was demonstrated in the addition of $1 \%$ essential oil sweet orange. The research also shows that the higher the addition of essential oils, the better the quality of liquid cement Boer goat.

\section{REFERENCES}

Aboagla, E. M. E., andT. Terada. 2004. Effects of supplementation of trehalosa extender containing egg yolk with sodium dodecyl sulfate on thefreezability of goat spermatozoa. Theriogenology. 62: 809-818.

Brinsko S.P., T.L. Blanchard, S.L. Rigby, C.C. Love and D.D. Varner. 2003. Effect of dead spermatozoa on motion characteristics and membrane integrity of live spermatozoa in fresh and cooled-storage equine semen.Theriogenology 59: 735-742.

Evans, G., and W. M. C. Maxwell 1987. Salamon's Artificial Insemination of Sheeps and Goats. Butterworths. London.

Feradis. 1999. Penggunaan Antioksidan Dalam Pengencer Semen Beku dan Metode Sinkronisasi Estrus Pada Program Inseminasi Buatan Domba St. Croix. Program Pascasarjana Institut Pertanian Bogor. Bogor.

Fisher, K., and C. A. Phillips. 2006. The effect of lemon, orange and bergamot essential oils and their components on the survival of Campylobacter jejuni, Escherichia coli O157, Listeria monocytogenes, Bacillus cereus and Staphylococcus aureus in vitro and in food systems. J Appl Microbiol. 2006 Dec;101(6):1232-40.

Hafez, E. S. E., and B. Hafez. 2000. Reproduction in Farm Animal 7 th ed. Lippincott Williams and Walkins, South Carolina. 
Hasan, S., S.M.H. Andrabi, R. Munir, M. Jehangir, P. Shafique, M. Anzar and N. Ahmad. 2000. Effect Of New Antibiotic Combination On Post-Thaw Semen Quality Of Buffalo And Sahiwal Bulls. $33^{\text {rd }}$ Annual Meet. Soc. Study Reprod., 62: 157.

Memon. A.A., H. Wahida, Y. Rosnina, Y.M. Gohb, M. Ebrahimi, F.M. Nadiac,G. Audrey. 2011. Effect of butylated hydroxytoluene on cryopreservation of Boer goat semen in Tris egg yolk extender. Animal Reproduction Science 129 (2011) 44 - 49.

Ogbuewu, I. P., N. O. Aladi., I. F. Etuk.,M. N. Opara.,M. C. Uchegbu.,I. C. Okoli., and M. U. Iloeje. 2010. Relevance of oxygen free radicals and antioxidants in sperm production and function. Journal of Veterinary Sciences 3 (3): 138-164.

Purdy, P. H. 2010. A Review on Goat Sperm Cryopreservation. Small Ruminat Research.

Rizal, M., and Herdis. 2008. Inseminasi Buatan Pada Domba. Jakarta. Rineka Cipta, Jakarta.

Toelihere, M.R. 1993. Inseminasi Buatan pada Ternak. Bandung: Angkasa.

Vishwanath, R. and P. Shannan. 2000. Storage of bovine in liquid and frozen state. Anim. Reprod. Sci. 62: 23-53.

Wendt, K.M., C.C. Love, S.P. Brinsko, J.A. Thompson, T.L. Blachard and D.D. Varner. 2002. Effect of extender pH on motility characteristics of cool-stored equine spermatozoa. Theriogenology 58 (2-4).

Zaituni U. 2012. Teknologi Inseminasi Buatan dan Transfer Embrio Pada Sapi. Sukabina Press. Padang 